\title{
UNDERSTAND THE APPLICATION OF QUALITATIVE RESEARCH IN INDONESIA
}

\author{
Mansur \\ Islamic Religious Institute Miftahul Ulum Pamekasan, Indonesia \\ elcmansur@gmail.com
}

\section{Introduction}

Qualitative research methods began in the era of the 1920-1930s which became the epistemological basis. Initially this method aims to understand social phenomena and states that experience is not an objective empirical reality, but is an event that can be learned from. A truth can be explored through a complete understanding and does not depend on only observed information but also on invisible data or information, which can then be dug deeper. In the 1960 s to 1970 s in America and in Germany this research experienced rapid development (Rennie, 2012).

Based on some of the literature, this qualitative research method experienced ups and downs in its development (Bennett-Levy and Beedie, 2007). Some experts say this research is divided into several periods. In contrast to quantitative research which dominated most of the 20th century (Merriam, 2001).

The rise of qualitative research methods brought by experts from the Chicago school in the 1920s focused more on social research such as history, social work, medicine, nursing and communication (Padgett, 2016). In addition, sub-disciplines such as cultural anthropology, ethnomethodology, phenomenology, cultural studies, feminism, symbolic interactionism and postmodernism are all based on the concept of reality and the nature of truth. Thus, qualitative research methods do not originate from one discipline, but from many social science disciplines simultaneously (Gerring, 2001).

Another opinion says that the period of qualitative research started from the 17th century to the 19th century where researchers were familiar with ethnographic methods. This ethnographic period also experienced stages from the early 20th century to 1960, and this lasted until 1980. Each of these periods has different priorities in viewing phenomena that occur in society. Meanwhile, in Indonesia, qualitative research began to occupy a stable position in the 2000s until now (Rukin, 2019).

\section{Variants Of Qualitative Research Methods}


According to Creswell (2007) this qualitative research method has 5 designs. Meanwhile, according to other authors, various designs. Jacob (1987) says there are 5 designs. Munhall (2012) calls it there are 3 designs. Laney (1993) calls it 6 designs. Corbin and Strauss (1990) say there are 5 designs. Morse (1994) mentions there are 4 designs. While Moustakas (1994) says there are 6 kinds of designs. The most according to Denzin and Lincoln (1995) who call it there are 9 designs. In contrast to Miles and Huberman (2002) who call it there are only 4 designs. While Slife and William (1995) call it also there are 4 designs. Of the various kinds of qualitative research designs, the author will explain only Creswell's version which calls it 5 designs. This is because it is more relevant to the Indonesian context.

Creswell (2007) mentions that the first qualitative research method is ethnography. Namely qualitative research related to the culture of society or a particular organizational field. The second, Grounded Theory, is a qualitative research method used to find theory. So theory is not built from thinking but is built from facts excavated from the field. The third is Case Study research which is used to understand a case. In other books, case studies are not only qualitative, they can also use quantitative and mixed methods (Abdillah, 2021). Then the fourth, namely phenomenology. A qualitative research that is used to understand the behavior of the informant, or it can be said to research the source of the data is the perpetrator. Next, the fifth is Narrative Research, which is researching about characters. The point is to make a biography or auto biography of a character.

So each writer is different in determining the number of qualitative research designs. Likewise in data analysis. Unlike quantitative methods, which are clear, both from the design, data collection techniques, data analysis instruments, everything is self-explanatory. So it is often said that the quantitative method is called the scientific method. Because everything is clear. While the qualitative method is often referred to as the artistic method. So this qualitative research method is an art. So that from one person to another in using this method the results are different (Cruz and Tantia, 2017).

\section{Qualitative Mindset}

In Indonesia, until now the implementation of qualitative research methods is used but in a positive mindset (Given, 2008). So this mindset is often used by academics who are afraid of statistics, so the mindset is quantitative but the data uses qualitative data. This is different from the inductive mindset, where qualitative methods are used for exploration, then finding categorizations, getting constructions and understanding the meaning of what is being studied (Malterud, 2001). 
If defined, this qualitative research is quite long, because it is summarized from various references. So Qualitative Research is a research method based on the philosophy of empiricism or post-positivism or interpretive. It is used to examine the condition of natural objects, where the researcher is the key instrument, data collection is done by triangulation (observation, interviews and documentation). qualitative data, the data analysis is inductive/qualitative and the results can be findings of potentials and problems, the uniqueness of the object of meaning of an event, processes and social interactions, certainty of the truth of the data, construction of phenomena and findings of hypotheses. So, qualitative research has more functions than quantitative research (Sugiono, 2007).

Thus, the qualitative research method that has existed so far, his philosophy uses empiricism, constructive and interpretive philosophy which is applied to natural objects (Alvesson and Sköldberg, 2017). This is in contrast to experimental research, which is conducted in a laboratory and is artificial in nature. The quantitative research method does not use closed instruments such as quantitative, but the instrument is the researcher himself. The reason is, because qualitative methods will find. If it finds, then there is no need to measure. Because it does not measure so there is no need to use an instrument.

In collecting data, jointly using observation, interviews and documentation. In this pandemic era, data collection using observation does not have to come to the field, because it is high risk, but can use online methods. The qualitative/inductive analysis model also varies greatly from one book to another. In contrast to quantitative analysis, which is clear, using descriptive inferential, parametric inference is statistically clear. While the results of qualitative research, can be descriptive, constructive, hypothetical findings and meaning.

\section{Functions of Qualitative Research Methods}

There are several functions of qualitative research methods for what are used in research, among others (Sugiono, 2017):

1. Qualitative Descriptive Function, where this qualitative description is applied by narrating the object under study. so it provides a narrative. The qualitative descriptive function is the lowest level that is duplicating or photographing objects.

2. The function of understanding the uniqueness of the phenomenon. This research is used to understand the uniqueness of the phenomenon. So this method does not want to generalize, but instead wants to examine something different or unique that has a certain advantage.

3. The function of ensuring the correctness of the data. That is to ensure the correctness of data from one source to another. For example, data on population, the Minister of Home 
Affairs and the Minister of Social Affairs submit data on different populations. It is necessary to look for the truth, which one is the most correct by using qualitative methods.

4. Function Research Process. That is research that presses to understand the nature of the process. To get the work process of a company, or the learning process, it is appropriate to use qualitative methods.

5. Function of Constructing Understanding. So in qualitative research, the data does not appear, then it is interpreted, but it is the researcher himself who constructs his understanding. For example, see a crowd. What's the crowd about? The thing that tells is the researcher himself. So it is the researcher who constructs an event.

6. Exploration Function. This function is the most important, where the qualitative method functions more to carry out exploration, so as to produce a finding (Kunaifi, 2021). If the quantitative method, namely thinking and then proven. from qualitative it proves thinking and proves hypotheses. But if qualitative it finds a hypothesis. Or simply, quantitative is developing science through proof of theory or thought, while qualitative is developing science and technology through exploration. So the difference between confirmation / proof with exploration.

7. Function of Understanding Meaning. Research that is more difficult than qualitative research methods is to understand the meaning of items 1 to 7 . because the functions 1 to 6 contain meaning. So each event needs to be interpreted. For example, seeing people cry, does it mean that the person is happy or in trouble or when they are emotional so they cry. So technically, qualitative research is actually more difficult than quantitative, because researchers have to 'find'. Because they are required to find, the researchers have to spend a long time in the field. Especially if the research aims to understand the meaning. So in terms of time, for qualitative research it can take a month, if quantitative, by running a questionnaire it may take 5 days.

\section{Examples and Cases in Indonesia}

Example of photographing objects. Initially taking pictures of the conditions outside, the courtyard, then the buildings, after a while they went inside. This activity is a descriptive qualitative research. That is, describing what is seen, both outside and inside. 


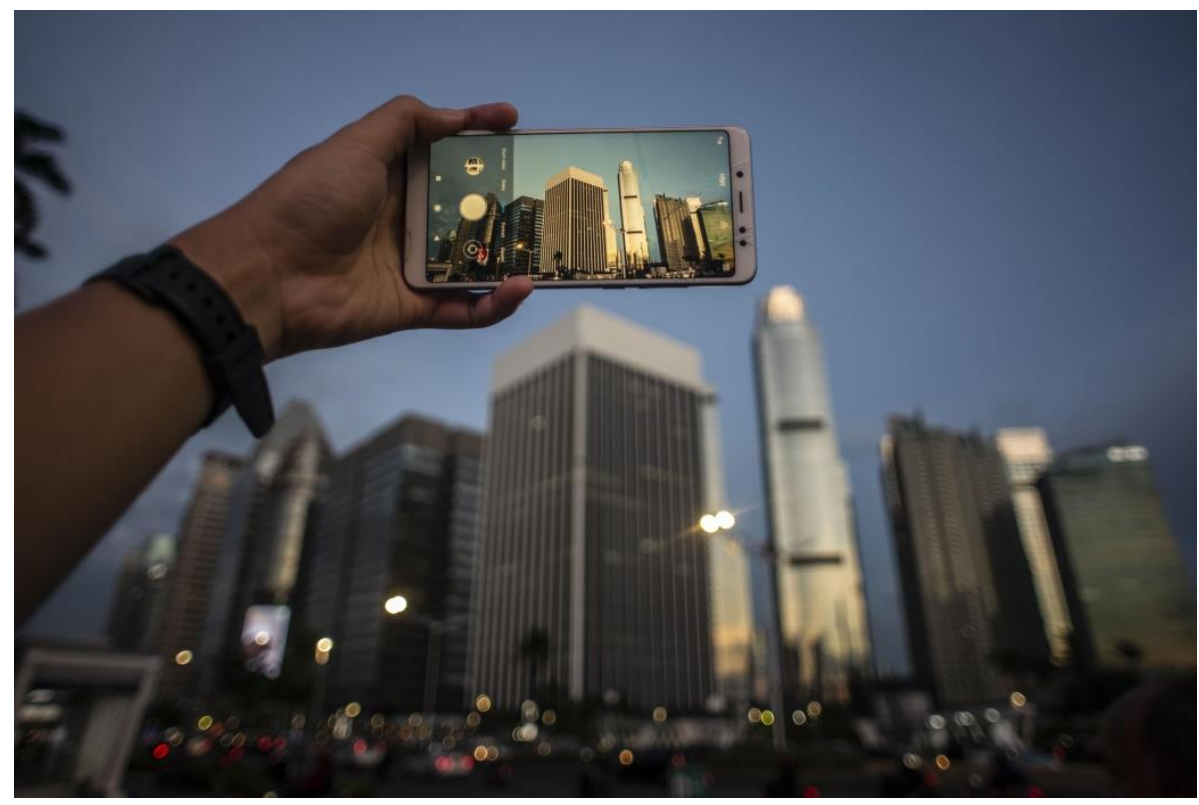

Figure 1. Photographing Objects

An example of a Unique Object is the Tower of Pisa. Generally, the leaning building is a negative event. This tower is tilted, but it can support one sub-district. This is a unique object. It's a negative thing, but it can actually make people live. In Jakarta, if there is a building that is tilted, instead of becoming a tourist attraction, people will shun it. This is a uniqueness of the object that is not owned elsewhere. Another example, such as coconut kopyor. Kopyor means damaged, but what is damaged is actually more expensive than normal.

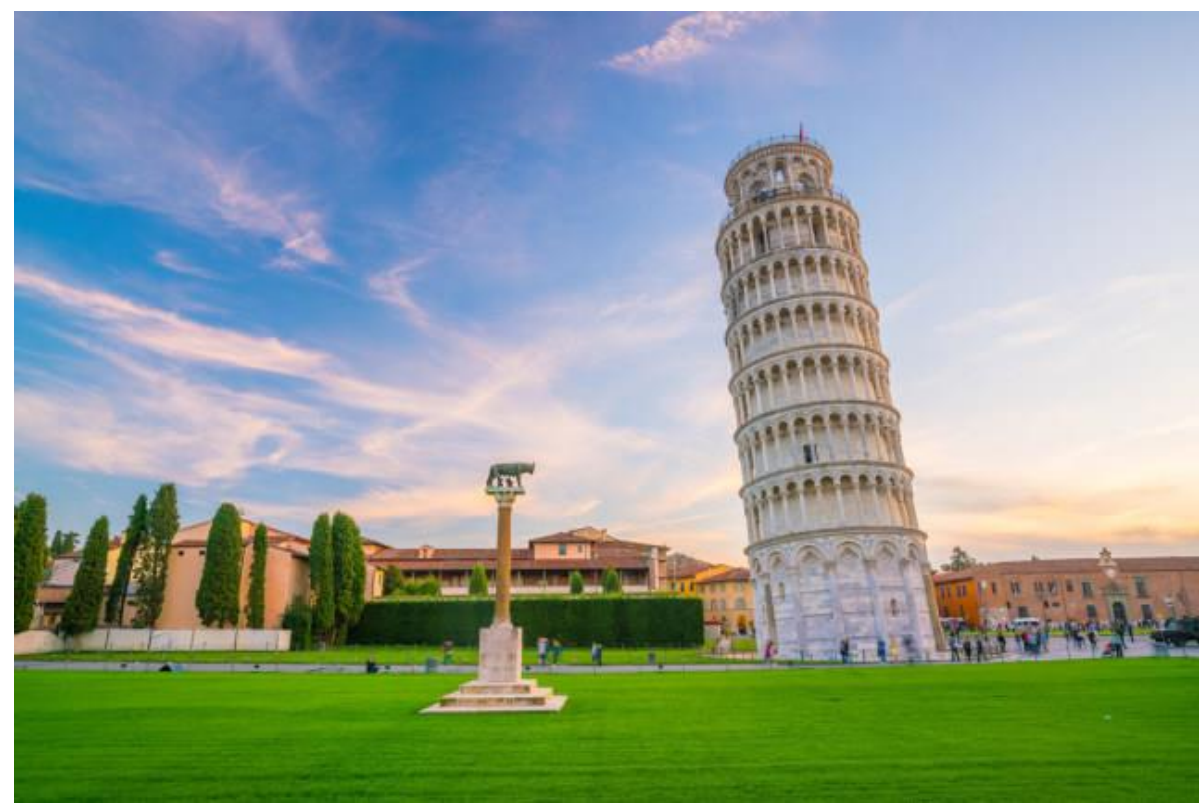

Figure 2. The Uniqueness of the Object of the Tower of Pisa

In Java (Indonesia) there is also a unique object, namely between Borobudur Temple and Prambanan Temple. in the IX century there has been an extraordinary level of knowledge 
from the Indonesian people, which in the 900s already had two extraordinary buildings. And apparently this building was built because of the competition between Buddhism and Hinduism. Borobudur Temple is a Buddhist temple, while Prambanan Temple is a Hindu temple. So each building also has a uniqueness of the object. Each of each building in terms of its shape, as well as the reliefs written on the body of the temple has a meaning that describes the society at that time. So Indonesia has been unique for 2 Millennium. In the first Millennium, Prambanan and Borobudur temples are the hallmarks of this Millennium. And the second millennium is the Majapahit kingdom.

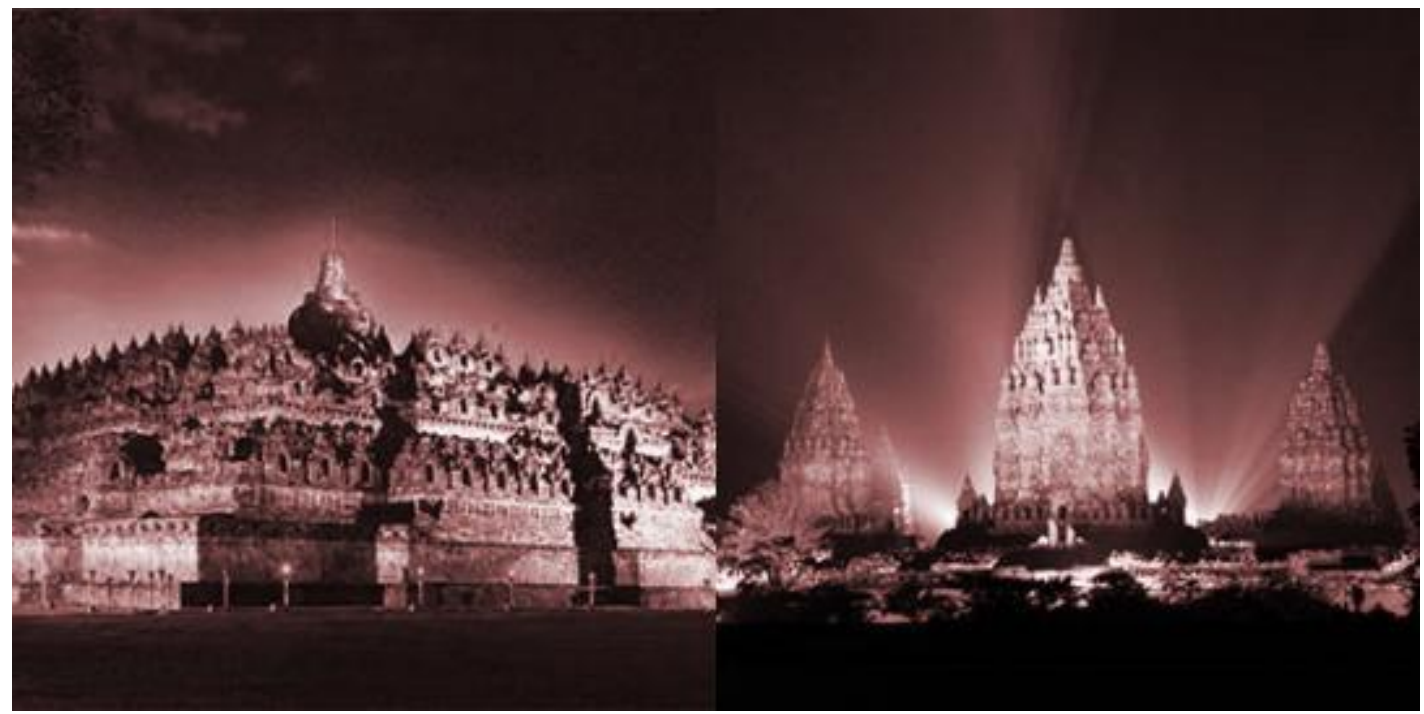

Figure 3. Borobudur Temple and Prambanan Temple, Indonesia

This qualitative research example is also used to ensure the truth of the object. This person argues, the one on the right says the number is 3 blocks, but the one on the left says the number is 4 . This is if in the count of the number of blocks there will be a conflict. So what is this happening for? Because the perception of understanding of the object from a different point of view. Why is it 3 on the right, but 4 on the left? This further needs to be confirmed.

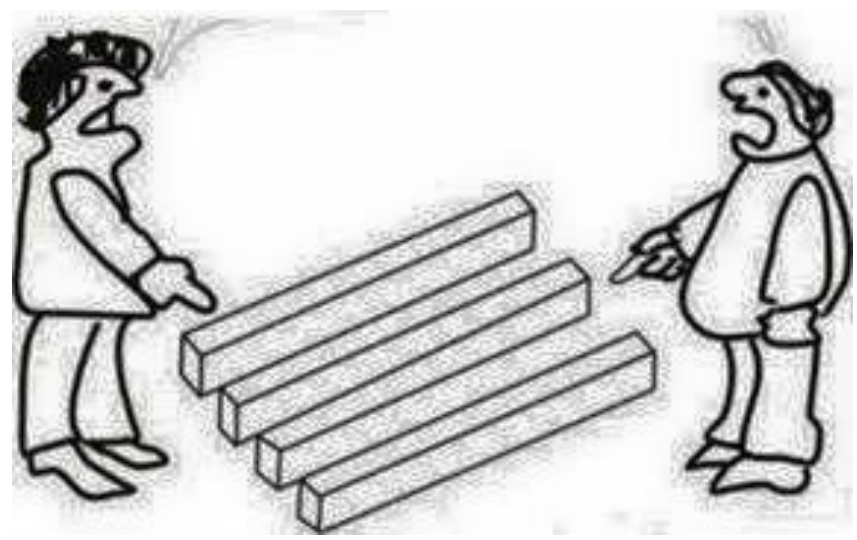

Figure 4. Confirming the Number of Blocks 
Examples of qualitative research that construct phenomena, in assessing objects can make different conclusions. Therefore, this research is subjective. In the example above, maybe we watch this picture is a picture of two people facing each other. But maybe other researchers see it as a flower pot. So one object but perceived differently by different people. So this qualitative method is subjective, although subjective does not mean wrong. Subjective, but not wrong because the point of view is different.
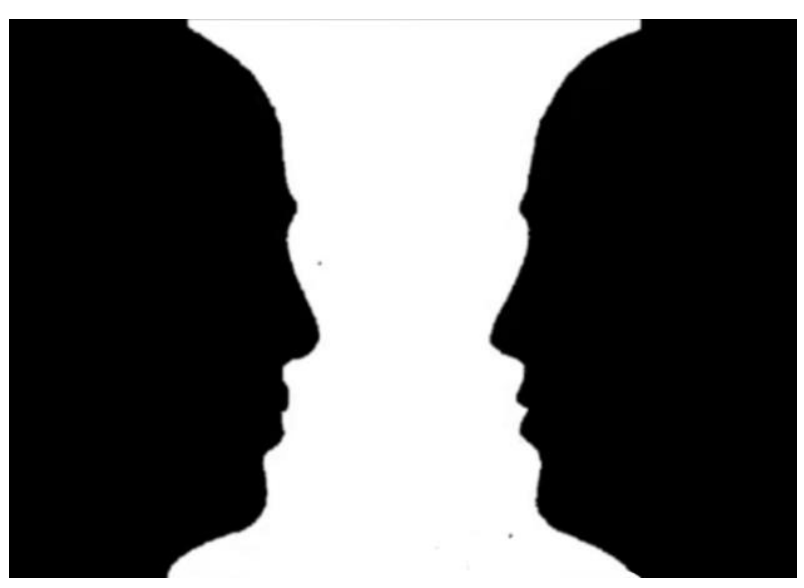

Figure 5. Flowerpot or Face to Face

In constructing one of these phenomena, one can construct one another so that it turns out that the phenomenon is in the form of a tree. it is a constructive training method; construct a phenomenon. but its construction is a visible phenomenon. because of goods But it can be seen from the point of view of direct constructive observation.

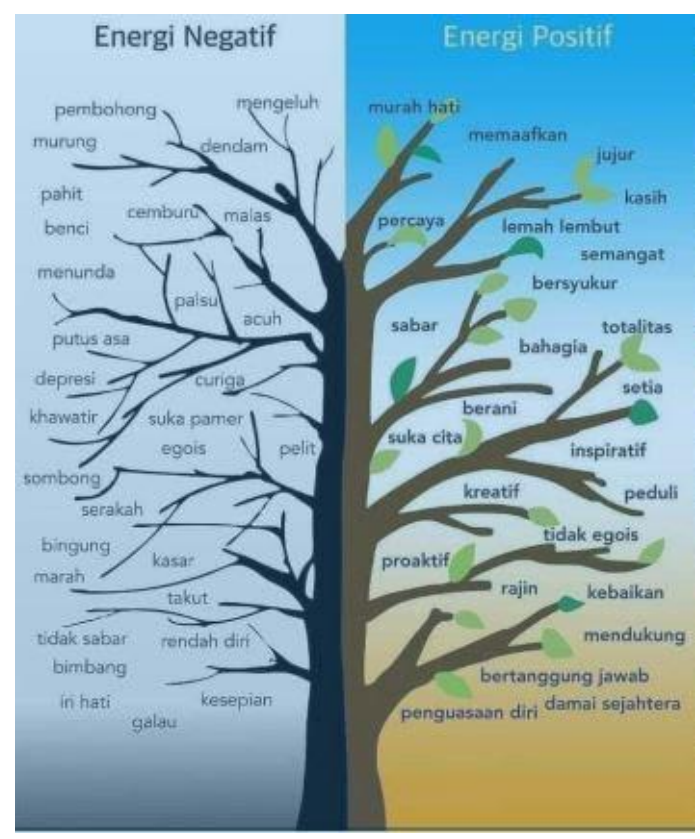

Figure 6. Positive and Negative Energy Trees

This is a remarkable finding from the qualitative method. Discover how each person has negative energy and positive energy. Amazing find for all of you must have this 
reference. If you want to be successful, use positive energy. Positive energy, for example from above, that a person must be generous, must forgive each other, must be honest, must be gentle, must be confident, must be enthusiastic, must be grateful and so on. A positive energy that needs to be done. Don't be on the left. This is negative energy, a source of failure. So from that exploration can be found as a performance tree, both positive and negative, the point is deep. And it's not just researching what it looks like. If you just look at it, it's called a quantitative method. Because the quantitative method can only examine the observable; which can be observed. While the qualitative method, which is exploratory in nature, is researching like an iceberg, what is being researched is not what is visible but is deep.

For example, researching about Corruption in Indonesia. Cultural corruption means that production is a negative behavior but is accepted by the community and does not protest. what is seen is the corruption in terms of the number, how many people. but instead, researchers must be able to dig deeply into the roots, what causes corruption. Because with corruption, many legal institutions have been established. from the police to the Prosecutor's Office, the judiciary, the police to the last to form the Corruption Eradication Commission (KPK). The existence of the KPK, because it no longer trusts other law enforcement officials. Even though there is a KPK, there is still corruption. Then what is the root of the problem, corruption cannot be eradicated? So this research is not finding the visible but finding meanings that are not visible. Even in carrying out the work of a project, the existence of corruption makes the work done faster and it turns out to be completed faster. But in the absence of corruption, those jobs are slower to get done. This is a phenomenon meaning. It needs to be explored in depth. So qualitative research is like researching an iceberg, not only what appears to be researched but also researched to the root. Thoroughly researched.

So qualitative research was initially exploring. The exploration of one researcher is different from another. There are researchers who only get to the surface. It's a bit deep. Some even research very deeply. By digging it, it is hoped will obtain a finding. And the findings go through the process, which is excavated. If the description of the process is observed, then it is described.

Case in point: Bung Karno. Bung Karno found meaning through digging stating, "I didn't create Pancasila, what I did was just dig deep into our earth, our own traditions and I found 5 beautiful pearls". So when viewed from a method, the method used by Bung Karno is a qualitative method, namely finding 5 items. The 5 pearls were finally referred to as the precepts in Pancasila. The first stage of the method is exploring, digging, finding 5 pearls and 
then the 5 grains can be categorized. So the process of excavation, then found various traditions that exist in Indonesia. Of the 5 traditions, it can be formulated into 5 which are called the 5 Precepts, namely: the tradition of worship or the tradition of carrying out their respective religions (the Precepts of the One Godhead). Then found that the Indonesian people have a high human nature, so that it is formulated into "just and civilized humanity". The Indonesian nation, between one tribe and another, wants to unite, starting with 1928 regarding the Youth Pledge. there already happened in 1928, while Pancasila was in 1945. And from the earth of Indonesia about a democratic model that is populist in nature led by wisdom in representative deliberation. This is now contradictory again, because in the past it was through representatives. But now I've seen it live. Means this is hardly noticed anymore in terms of materials. Fifth, through this exploration, it is found aspects of community behavior that demand justice. So Bung Karno dug up the earth of Pancasila and found these five pearls if in the qualitative method they were categorized. After being categorized and then constructed between the five pearls, it turns out that they have a relationship with each other. They are related to each other, there are only 5 pearls left, the theme or title is called: Pancasila. This is an example of exploring meanings that are easy to understand, starting with: exploring, categorizing, then creating themes (Sugiono, 2021).

\section{Conclusion}

The application of qualitative research methods in Indonesia is more appropriate to use the concepts offered by Creswell, namely: ethnography, phenomenology, case studies, grounded theory and narratives. The functions of qualitative research include those that can be used to describe qualitative data, understand the uniqueness of phenomena, ensure data validity, process research, construct understanding, explore, and understand meaning. Of these several functions of qualitative research, the most difficult to do is to understand the meaning of all functions of qualitative research. For this reason, it is necessary to carry out systematic steps starting from digging up the data, then continuing with categorizing, and then creating themes. The example of the case carried out by Bung Karno in exploring the traditions in Indonesia so that he gave birth to five pearls which were then summarized in the five precepts, which was later called Pancasila, is an example of understanding the best meaning that Indonesia has.

\section{Reference}

Abdillah, L. A. . . [et. al. . (2021) Metode Penelitian dan Analisis Data Comprehensive. 1st edn. Edited by Z. Said Subhan Posangi, Indah Kusumawati. Cirebon: Insania.

Alvesson, M. and Sköldberg, K. (2017) Reflexive methodology: New vistas for qualitative 
research. sage.

Bennett-Levy, J. and Beedie, A. (2007) 'The ups and downs of cognitive therapy training:

What happens to trainees' perception of their competence during a cognitive therapy training course?', Behavioural and Cognitive Psychotherapy, 35(1), pp. 61-75.

Corbin, J. M. and Strauss, A. (1990) 'Grounded theory research: Procedures, canons, and evaluative criteria', Qualitative sociology, 13(1), pp. 3-21.

Creswell, J. W. et al. (2007) 'Qualitative research designs: Selection and implementation', The counseling psychologist, 35(2), pp. 236-264.

Cruz, R. F. and Tantia, J. F. (2017) 'Reading and understanding qualitative research', American Journal of Dance Therapy, 39(1), pp. 79-92.

Denzin, N. K. and Lincoln, Y. S. (1995) 'Transforming qualitative research methods: Is it a revolution?', Journal of Contemporary Ethnography, 24(3), pp. 349-358.

Gerring, J. (2001) Social science methodology: A criterial framework. cambridge university Press.

Given, L. M. (2008) The Sage encyclopedia of qualitative research methods. Sage publications.

Huberman, M. and Miles, M. B. (2002) The qualitative researcher's companion. Sage.

Jacob, E. (1987) 'Qualitative research traditions: A review', Review of educational research, 57(1), pp. 1-50.

Kunaifi, A. (2021) 'Quantitative Easing In Overcoming the Crisis: Criticism ofQeinthe Monetary System Of Capitalism', Turkish Journal of Computer and Mathematics Education (TURCOMAT), 12(3), pp. 3703-3714.

Malterud, K. (2001) 'Qualitative research: standards, challenges, and guidelines', The lancet, 358(9280), pp. 483-488.

Merriam, D. F. (2001) 'Andrei Borisovich Vistelius: a dominant figure in 20th Century mathematical geology', Natural resources research, 10(4), pp. 297-304.

Morse, J. M. (1994) Critical issues in qualitative research methods. sage.

Moustakas, C. (1994) Phenomenological research methods. Sage publications.

Munhall, P. (2012) Nursing research. Jones \& Bartlett Learning.

Padgett, D. K. (2016) Qualitative methods in social work research. Sage publications.

Rennie, D. L. (2012) 'Qualitative research as methodical hermeneutics.', Psychological methods, 17(3), p. 385.

Rukin, S. P. (2019) Metodologi Penelitian Kualitatif. Yayasan Ahmar Cendekia Indonesia.

Slife, B. D., Williams, R. N. and Williams, R. N. (1995) What's behind the research?:

Discovering hidden assumptions in the behavioral sciences. Sage.

Sugiono (2007) Metode Penelitian Kuantitatif Kuantitatif, Pendekatan kualitatif dan R\&D,

Bandung: Alfabeta.

Sugiono (2017) Metode Penelitian Kombinasi Mixed Method. Bandung: Bandung, Alfabeta.

Yon, M. G., Mickelson, R. A. and Carlton-LaNey, I. (1993) 'A child's place: Developing interagency collaboration on behalf of homeless children', Education and Urban Society, 25(4), pp. 410-423. 